Earth Common Journal Regular Issue The Voice of Change

MacEwan University

Volume 3, Number 1, September 2013

\title{
Conserving China's Biodiversity
}

Kevin Pyne*

MacEwan University, Canada

\begin{abstract}
Over the past several decades, with the introduction of ecology as a scientific pursuit, China has made advancements in ensuring the health and sustainability of its forests and biodiversity. A very large number of endemic plant and vertebrate species are found in China, plenty of which have value in many areas, including aesthetics and medicine. China's biodiversity faces many threats, including the invasion of alien species, urbanization and deforestation, as well as global warming. As the monetary value of the products obtained from the many endemic species has been recognized, an increase in environmental awareness has surfaced. Several domestic and international environmental non-governmental organizations (ENGOs) committed to the preservation of China's forests and wildlife have played an increasing role in educating both the Chinese and the rest of the world. The major issue concerning the preservation of China's biodiversity is a lack of education in the biological sciences. Increased funding to attract more educated people to work in the Ministry of the Environment, as well as to aid in educating more people is the first logical step.
\end{abstract}




\section{Introduction}

Loss of biodiversity is becoming an increasing global concern. What is biodiversity and why is it important? It can be described as the variety of living organisms on earth, the range of species, the genetic variability within species and the different characteristics taken on by ecosystems (McBeath \& McBeath 2006, p.293). Some estimates state that currently over one thousand species are lost per year, compared to only about four per year before the arrival of humans (McBeath \& McBeath, 2006, p. 293).

In China, there are a large variety of species, including a considerable amount of endemic species. An endemic species is one that is restricted to a certain region (Lawrence, 2008, p. 201). It is one of the world's most diverse countries with respect to biodiversity, housing more than ten percent of the world's known species (McBeath \& McBeath, 2006, p. 293). China is home to more than 35, 000 species of vascular plants (Ministry of Environmental Protection, 2008, p. i; Liu et al., 2003, p. 1240), and nearly 6500 species of vertebrates (Ministry of Environmental Protection, 2008, p. i), of which, respectively, approximately 17,300 and 667 are endemic (Ministry of Environmental Protection, 2008, p. i).

There are several reasons for the high levels of endemism found in China, including: topographical isolation around the mountain ranges, its large size, approximately 9.6 million $\mathrm{km}^{2}$ (Huang et al., 2010, p.1252) — which gives it a great range of physical characteristics - and the fact that it is an ancient center for evolution (McBeath \& McBeath, 2006, p. 316). Of these, topographical isolation seems to have played the largest part (Xu et al., 2009, p. 522).

We find high instances of both paleoendemism, the survival of ancient organisms due to being situated in high elevations, and neoendemism, the speciation of new organisms due to the wide variety of ecological niches provided to them with few competitors (Xu et al., 2009, p.522). Due to the high levels of endemic species found in China, preserving its forests and natural ecosystems should be a priority not only for the people of China, but for the entire globe.

Beyond the obvious aesthetic value of such species as the Chinese icon giant panda (Ailuropoda melanoleuca) (Morell, 2008, p. 1442) or the Asiatic elephant (Elephas maximus) (McBeath \& McBeath, 2006, p.296), we also use China's biodiversity for a plethora of useful items. We also find plants that we would find in almost every garden in North America; the rhododendron (Rhododendron spp.), primrose (Primulaceae spp.), and lily (Lilium spp.) (Morell, 2008, p. 1442). Other plants with either economic or medicinal 
value include, but are not limited to, Liquorice spp., Ephedra sinica stapf, Aweto spp., Snow lotuse, and Saline cistanche (Ministry of Environmental Protection, 2008, p. 4).

An increasing loss of species threatens human's ability to use those species for tasks such as air and food purification, as well as the compounds extracted from certain organisms used in medicines (McBeath \& McBeath, 2006, p. 296). In terms of economics, it has been estimated that species extinctions and threats to ecosystems could cost as much as $\$ 33$ trillion (McBeath \& McBeath, 2006, p. 294).

Up until the 1950's, China showed reasonable judgment when it came to protecting its natural resources. As it turns out, they were just waiting for an industrial revolution of their own. When the Peoples Republic of China was established in 1949 under Mao Zedong, very little attention was given to a preservationist attitude (McBeath \& McBeath, 2006, p. 297). With movements like the Great Leap Forward (1958 - 1961) and the Cultural Revolution (1966 - 1976) (McBeath \& McBeath, 2006, p. 297), China saw an increase in its timber harvest from 20 million $\mathrm{m}^{3} /$ year in the 1950 's to 60 million $\mathrm{m}^{3}$ /year in the 1990's (Zhang et al., 2000, p. 2135).

It is estimated that approximately $90 \%$ of China's grasslands are experiencing some sort of degradation and about $40 \%$ of China's major wetlands are experiencing serious degradation, with special concern given to coastal mudflats and mangroves (Ministry of Environmental Protection, 2008, p. 5). A growing academic and environmentalist movement, combined with natural disasters caused directly by overconsumption - for example, the two floods along the Yangtze River in 1981 and 1998, the second of which caused an estimated \$20 billion and claimed 1500 lives (Morell, 2008, p. 1442) - have forced governments into action and new policies and agencies like the National Forest Conservation Program (NFCP) (Zhang et al., 2000, p.2135) have been created.

This article will describe the challenges China faces in dealing with biodiversity; specifically, problems of industrialization and expansion, the invasion of alien species, and, of course, global warming. Government practices and policies will be evaluated, including its recognition of nature reserves and national parks. As well, governmental agencies and non-governmental organizations involved in the conservation of China's biodiversity will be surveyed.

\section{Challenges / Threats}

The major threats to the conservation of natural ecosystems in China are rapid expansion and industrialization. There are currently just over 19,000 small cities in 
China_ up from about 3000 twenty years ago — and another 50,000 towns are currently being developed (Lu et al., 2011, p. 1710). With this, China has seen a rise in urbanization and GDP, ranking as the second largest economy in the world (Lu et al., 2011, p. 1710). The obvious consequence of all this growth is an increased demand for agricultural and timber products 'Zhang et al., 2000, p.2135; Lu et al., 2011, p. 1710).

Along the Qionglai Mountain Range in China's Sichuan province' dense forests were destroyed beginning in the 1950's and escalating in the 1970's (Morell, 2008, p. 1442). Reports in 1998 that underestimated the extent of threats faced by China's species have since been refuted with the actual results being far more severe than previously assessed (Ministry of Environmental Protection, 2008, p. 5). A booming tourism industry has led the degradation of protected areas (Wang \& Jia, 2012, p. 25). The Chinese are also culpable of excessive reclamation, massive water conservancy projects such as dams, railway and highway construction, as well as the discharge of industrial and municipal wastes (Ministry of Environmental Protection, 2008, p. 6). All of these activities are the product of rapid growth and urbanization and all are harmful to the longevity of natural ecosystems.

One of the results of the massive growth of China's industrial complex is the invasion of alien species, one of the most important factors endangering biodiversity (Xu et al., 2006, p. 2893). They expedite the loss of species and genetic biodiversity, destroy the harmonious structure and function of an ecosystem, and can even cause tremendous economic losses (Xu et al., 2006, p. 2901).

An invasive alien species can be defined as an alien species that establishes itself in natural habitats, is an agent of change, and threatens native biological diversity (Xu et al., 2006, p. 2894). More than half of the invasive species in China are terrestrial plants originating from North or South America (Xu et al., 2006, p. 2895). About half of the invasive species in China were introduced unintentionally, with about $40 \%$ being introduced intentionally as a means for turning a profit and almost $60 \%$ of all invasive species have invaded valuable agricultural land (Xu et al., 2006, p. 2895). Black rot of sweet potato (Ceratocystis fimbriata) and cotton verticillium wilt (Verticillium dablia) are just a couple of the microorganisms which bear diseases in crops that are invasive alien species brought to China through timber or soil (Xu et al., 2006, p. 2897). There are 188 invasive alien plants in China that found their way there via introduction as useful plants, natural dispersion from neighboring countries, introduction through farm products, or invasion via imported wheat seeds (Xu et al., 2006, p. 2897). Approximately $25 \%$ of the invasive alien animal species were introduced intentionally - such as the Bullfrog, which 
was bred for characteristics of big body, rapid growth, and tastiness (Xu et al., 2006, p. 2899 ) - compared to $76.3 \%$ being introduced unintentionally.

Some estimates say invasive alien species have caused losses ranging up to \$138 billion in the United States ( Xu et al., 2006, p. 1496). Xu and his colleagues (2006) conducted a study examining data collected from 2001 to 2003 regarding invasive alien species in China and determined that direct economic losses - direct goods damage caused by invasive alien species to be $\$ 2.397$ billion with losses in agriculture taking the biggest hit at $61.48 \%$ (p. 1498). The same study determined indirect economic losses loss of serviceable function of ecosystems - caused by alien invasive species to be $\$ 12.056$ billion (p. 1499), with losses to forest and agricultural ecosystems losing $\$ 1.959$ billion and $\$ 1.404$ billion (p.1499), respectively. The total direct and indirect economic losses from this study added up to $\$ 14.45$ billion, or $1.36 \%$ of China’s GDP in 2000 (p. 1499).

Of course, climate change plays a role in the loss of biodiversity, albeit a minor one compared to the threats of industrialization and invasive alien species. The major threat is the melting of glacial ice atop the Himalayan mountain ranges as global temperatures rise. Warming at high elevations occurs at three times the global average and annual mean warming is expected to be around $3^{\circ} \mathrm{C}$ by 2050 and $5^{\circ} \mathrm{C}$ by 2080 (Xu et al., 2009, p. 522). This runs the risk of increased melting, and thus increased soil erosion, flooding, and quicker depletion of $25 \%$ of the Chinese populations' water supply (Xu et al., 2009, p. 522). The threats also extend to alpine plants, synchronous predator-prey relationships, increased invasions of alien species and endemic species being especially vulnerable due to their limited geographic range (Xu et al., 2009, p. 524 - 525).

\section{Government Practice / Policy}

Throughout much of the latter half of the $20^{\text {th }}$ century, the centralized Chinese government paid little attention to conservation and protection of its wildlife. It was not until the 1980s that the National People's Congress enacted the first forest legislation. The Grassland Law was enacted in 1985, which described principles for forest management, set up a timber harvest quota system, and required permits for shipping timber (McBeath \& McBeath, 2006, p. 298). Protection of China's forests is critical not only due to the high levels of species - especially endemic species - throughout their forests (Hou et al., 2010, p. 378), but also because of the threats to globally cherished mammal species like the black-crested gibbon (Nomascus concolor) (Peng-Fei et al., 2009, p. 203). The greatest number of $N$. concolor are found in China and they are especially sensitive to habitat destruction (Peng-Fei et al., 2009, p. 203), so the protection of China's 
forests is essential to the survival of this species. Although in recent years there has been extensive dam construction for hydroelectric power in some of China's forested areas along the Yangtze River, forest conservation has remained a priority (Guo et al., 2007, p. 1558).

To its credit, China has taken action by rapidly establishing a large number of nature reserves, parks and other protected areas since the 1990s (McBeath \& McBeath, 2006, p. 316). As of 2011, 2538 nature reserves had been established, with more than $50 \%$ of these being established since 1995 (Zhou \& Grumbine, 2011, p. 1315). These reserves cover more than 15\% of China's land mass (Zhou \& Grumbine, 2011, p. 1315). But what is a nature reserve?

Protected areas in China include three separate management zones, core areas, buffer zones, and experimental zones. Core areas are not to be used for habitation or any other reason apart from limited scientific research. Buffer zones are areas where habitation is still not permitted, but there is more access for scientific research, along with some collection and measurements by amateurs. Finally, the experimental zone is where scientific investigation, public education, tourism, and raising rare endangered species are permitted (McBeath \& McBeath, 2006, p. 299). This zoning system copies the same one proposed by UNESCO for use in Biosphere Reserves (McBeath \& McBeath, 2006, p. 299).

The issues associated with China's nature reserves revolve around funding and management capacity. In order to fund its natural reserves, China has adopted an American-style, free-market strategy, relying on funding from local authorities and large international corporations (Zhou \& Grumbine, 2011, p. 1315). Also, it has been reported that the employees working in natural reserves have minimal education about the biological sciences, and ecology in general, with a recent study indicating that only about one third of China's nature reserve staff have adequate training (Zhou \& Grumbine, 2011, p. 1315). Until the federal government begins to increase funding for its natural reserves, this problem will not be ameliorated.

\section{Governmental Agencies}

There are five major agencies within China's government overseeing environmental protection, the National Environmental Protection Agency (NEPA), the State Forestry Administration (SFA), the Ministry of Agriculture (MOA), the Ministry of Construction (MOC), and the State Oceans Administration (SOA). The National Environmental Protection Agency (NEPA) was established in 1988, but was subsequently changed to 
the State Environmental Protection Agency (SEPA) in 1998. It is responsible for all issues concerning environmental protection and has a department of nature conservation, along with a division of nature reserves and species management (McBeath \& McBeath, 2006, p. 301). SEPA has ministerial status (McBeath \& McBeath, 2006, p. 301).

The State Forestry Administration (SFA) is sub-ministerial and is primarily responsible for $75 \%$ of China's nature reserves, as well as the implementation of legislation designed to protect the environment (McBeath \& McBeath, 2006, p. 301). The Ministry of Agriculture (MOA) directs about 3\% of protected areas and has a small office for endangered and threatened species, which includes aquatic species (McBeath \& McBeath, 2006, p. 301). The Ministry of Construction (MOC) oversees parks recognized as UNESCO heritage sites (McBeath \& McBeath, 2006, p. 301), of which 21 have been designated (Liu et al., 2003, p. 1240), as well as regulating the Chinese zoo system (McBeath \& McBeath, 2006, p. 302). The State Oceans Administration (SOA) is responsible for all endangered species two hundred miles off the coast of China, as well as a few marine protected areas (McBeath \& McBeath, 2006, p. 302).

\section{Non-Governmental Organizations}

As of 2006, there were approximately two thousand Environmental NonGovernmental Organizations (ENGOs). Some of the more active are well-known international organizations such as Greenpeace, International Fund for Animal Welfare (IFAW), and the World Wildlife Fund (WWF) (McBeath \& McBeath, 2006, p. 305 306). Friends of Nature (FON) was the first ENGO established in China, it is mainly focused on education of environmental issues and is heavily relied upon by the Chinese press for information regarding environmental problems (McBeath \& McBeath, 2006, p. 305). Founded in 1995, Beijing-based Wetlands International is an organization which concentrates its efforts on threats to wetlands from economic development, pollution, and climate change (McBeath \& McBeath, 2006, p. 304). And lastly, the Desert Control Volunteers Network was established to change attitudes about desertification by educating China's urban population about special landforms, plants, and animals found in desert regions (McBeath \& McBeath, 2006, p. 306).

\section{Conclusion}

China is a very unique and important country when it comes to biodiversity. It not only has a large range of species, but also possesses a very large endemic population. One of the main concerns regarding conservation of biodiversity in China is balancing 
environmental concerns with growing cultural and economic demands (McBeath \& McBeath, 2006, p. 295). Initially, the Chinese were not concerned with environmental protection, but natural disasters and an increasing environmentalist movement have forced governments into action. With the implementation of more than 2500 nature reserves and the creation of several governmental agencies, the Chinese are on the right path to the conservation of its biodiversity.

Two of the positive signs are the increase in the giant panda (Ailuropoda melanoleuca) population (McBeath \& McBeath, 2006, p. 316) and forest coverage has increased from 8.6\% in 1949 to $18.2 \%$ in 2008 (Ministry of Environmental Protection, 2008, p. 5). As well, people from around the globe have begun to realize the importance of preserving China's forests and wildlife, as multiple ENGOs have been formed with a focus on preserving China's forests and the species that inhabit them.

With the good comes the bad. The real downfall with China's approach to conservation is that they are poorly educated in the biological sciences. The official study of ecology has only been around in China for the better part of two decades (McBeath \& McBeath, 2006, p. 310). Because of this, we see inadequate funding from the federal government towards ecological pursuits, leading to inadequate knowledge and training amongst the people employed at nature reserves. As well, the government still seems to be more concerned with development than it does with protecting the environment (McBeath \& McBeath, 2006, p. 317).

China is on the right track to preserving their biodiversity, and it is still considered a developing nation. As mentioned above, it is still new at the practice of environmental protection. With increased education from the Western world, along with increased funding from its own federal government, China has the potential to become an international model for environmental protection.

* Author: Kevin Pyne was born in Nipawin, Saskatchewan in 1987 and moved to Alberta in 1992, when his family moved to Edson, Alberta. Kevin is currently three semesters away from obtaining his Bachelor of Science degree with a major in Biological Sciences from MacEwan University. Eventually, Kevin wants to attend Graduate School at either UBC in V ancouver, Carleton University in Ottawa, or Ryerson University in Toronto to obtain a Masters in Journalism. Kevin has a keen interest in evolutionary biology, vertebrate zoology, and empirical thinking in general. He also has many interests outside of science, including politics, the media, and public discourse. 


\section{References}

Guo, Z., Li, Y., Xiao, X., Zhang, L., Gan, Y. (2007). Hydroelectricity Production and Forest Conservation in Watersheds. Ecological Applications 17(6): 1557 - 1562.

Hou, M.F., Lopez-Pujol, J., Qin, H.N., Wang, L.S., Liu, Y. (2010). Distribution pattern and conservation priorities for vascular plants in Southern China: Guangxi Province as a case study. Botanical Studies 51: 377 - 386.

Huang, Q.Q., Qian, C., Wang, Y., Jia, X., Dai, X.F., Zhang, H., He, F., Peng, S.L., ang, G.X. (2010). Determinants of the geographical extent of invasive plants in China: effects of biographical origin, life cycle and time since introduction. Biodivers Conserv 19: $1251-1259$.

Lawrence, E. (2008). Henderson's Dictionary of Biology (14 ${ }^{\text {th }}$ ed.). Harlow, England: Pearson Education Limited

Liu, J, Ouyang, Z., Pimm, S.L., Raven, P.H., Wang, X., Miao, H., Han, N, (2003). Protecting China's Biodiversity. Science 300: 1240 - 1241.

Lu, Q., Liang, F., Bi, X., Duffy, R., Zhao, Z. (2011). Effects of urbanization and industrialization on agricultural land use in Shandong Peninsula of China. Ecological Indicators 11: 1710 - 1714.

McBeath, J., McBeath, J.H. (2006). Biodiversity Conservation in China: Policies and Practice. Journal of International Wildlife Law and Policy 9: 293 - 317.

Ministry of Environmental Protection (2008). China's Fourth National Report on Implementation of the Conservation on Biological Diversity.

Morell, V. (2008). Letting 1000 Forests Bloom. Science 320: 1442 - 1443.

Peng-Fei, F., Xue-Long, J., Chang-Cheng, T. (2009). The Critically Endangered black crested gibbon Nomascus concolor on Wuliang Mountain, Yunnan, China: the role of forest types in the species' conservation. Oryx 43(2): $203-208$.

Wang, P.W., Jia, J.B. (2012). Tourists' willingness to pay for biodiversity conservation and environment protection, Dalai Lake protected area: Implications for entrance fee and sustainable management. Ocean \& Coastal Management 62: 24 - 33.

Xu, H., Qiang, S., Han, Z., Guo, J., Huang, Z., Sun, H., He, S., Ding, H., Wu, H., Wan, F. (2006). The status and causes of alien species invasion in China. Biodiversity and Conservation 15: 2893 - 2904. 
Xu, J, Grumbine, R.E., Shrestha, A., Eriksson, M., Yang, X., Wang, Y., Wilkes, A. (2009). The Melting Himalayas: Cascading Effects of Climate Change on Water, Biodiversity, and Livelihoods. Conservation Biology 23(3): 520 - 530.

Xu, H., Ding, H., Li, M., Qiang, S., Guo, J., Han, Z., Huang, Z., Sun, H., He, S., Wu, H., Wan, F. (2006). The distribution and economic losses of alien species invasion in China. Biological Invasions 8: 1495 - 1500.

Zhang, P., Shao, G., Zhao, G., Le Master, D.C., Parker, G.R., Dunning, J.B., Li, Q., (2000). China's Forest Policy for the $21^{\text {st }}$ Century. Science 288: $2135-2136$.

Zhou, D.Q., Grumbine, R.E. (2011). National parks in China: Experiments with protecting nature and human livelihoods in Yunnan province, Peoples' Republic of China (PRC). Biological Conservation 144: 1314 - 1321. 